
\title{
$\begin{array}{ll}\text { Research Square } & \begin{array}{l}\text { Preprints are preliminary reports that have not undergone peer review. } \\ \text { They should not be considered conclusive, used to inform clinical practice, } \\ \text { or referenced by the media as validated information. }\end{array}\end{array}$
}

\section{Evaluation of an Educational Strategy to Improve Medication Reconciliation in Ambulatory Care}

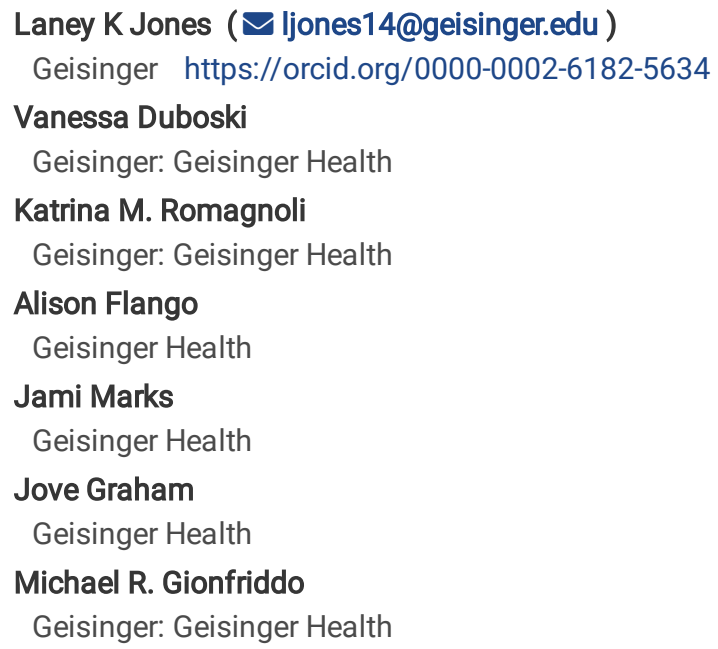

\section{Research}

Keywords: Medication reconciliation, pharmacist-led interventions, ambulatory, conceptual model of implementation research, implementation outcomes

Posted Date: August 13th, 2021

DOI: https://doi.org/10.21203/rs.3.rs-764311/v1

License: (c) This work is licensed under a Creative Commons Attribution 4.0 International License. Read Full License

Version of Record: A version of this preprint was published at Journal of the American Pharmacists Association on January 1st, 2022. See the published version at https://doi.org/10.1016/j.japh.2022.01.010. 


\section{Abstract}

Introduction. Improper medication reconciliation can result in inaccurate medication lists which can lead to adverse events including hospitalizations. Interventions targeting medication reconciliation have had varying levels of success. To improve medication reconciliation practices in our ambulatory care clinics, we developed an educational program for clinic personnel. The objective of this study is to describe the educational program, its implementation in a healthcare system, pharmacist and clinic personnel perception of the program, and its impact on clinic personnel knowledge and practice.

Methods. Guided by the Conceptual Model of Implementation Research, we conducted an evaluation of a pharmacist-led educational program on evidence-based practices for medication reconciliation by examining implementation outcomes. The implementation outcomes measured include penetration, fidelity, acceptability, appropriateness, feasibility, and adoption. Data was collected through direct observations, administrative data, pre- and post-surveys, and semi-structured interviews.

Results. A total of $37 / 46$ (80\%) primary care sites implemented the pharmacist delivered medication reconciliation education from April to June 2021 with representation from each of Geisinger's regions. Ten (27\%) clinic sites completed the medication reconciliation educational program as originally designed, with the remainder adapting the program. A total of 296 clinic personnel completed the pre-survey, while 178 completed the post-survey. There were no statistically significant differences in baseline characteristics between clinic personnel who completed the pre- vs. post-survey. Interviews were completed with 11 clinic personnel who attended the educational program and 4 pharmacists who delivered the educational program. All clinic personnel interviewed felt satisfied with the educational program and felt it was appropriate since it directly impacted their job. While clinic personnel felt the educational program was acceptable and appropriate, two major concerns were discussed: lack of patient knowledge about their medications and lack of time to complete the medication reconciliation. We found the adherence rate to the elements of the medication reconciliation which were covered in the education program ranged from $0 \%$ to $95 \%$ in the 55 observations conducted.

Conclusion. An educational program for medication reconciliation was found to be acceptable and appropriate but was often adapted to fit site specific needs. Additional barriers affected adoption of best practices and should be addressed in future studies.

Trial registration. N/A

\section{Contributions To The Literature}

- Implementing effective medication reconciliation programs that reduce adverse events and hospitalizations poses a problem for healthcare systems.

- Implementation science can help to understand the barriers associated with medication reconciliation and the development of targeted strategies to address these barriers.

- Testing site-specific adapted programs, such as the educational program in this study, may help improve the medication reconciliation process.

\section{Introduction}

Improper medication reconciliation can result in inaccurate medication lists which can lead to adverse events including hospitalization (1-3). Inaccuracies in medication lists are common and may contribute to 100,000 hospitalizations per year (1-3). There are many factors contributing to an improper medication reconciliation including patients' lack of knowledge of their medications, lack of a standardized process for conducting medication reconciliation by healthcare centers, and a lack of education for healthcare workers on how to conduct a proper medication reconciliation (4). Interventions to improve medication reconciliation often target one or more of these barriers and have had varying levels of success in improving the process.

In a previous study, we identified a lack of training on proper medication reconciliation as one of the major barriers to accurate medication lists (4). To address this barrier, we designed and implemented a pharmacist-led educational program for healthcare staff in our ambulatory care clinics. The objective of this paper is to describe the training, its rollout in a healthcare system, pharmacist and clinic personnel perception of the training, and the impact of the training on medical personnel knowledge and practice. Guided by the Conceptual Model of Implementation Research $(5,6)$, we collected and measured implementation outcomes important to the success of the pharmacist-led educational program within a healthcare system.

\section{Methods}

\section{Setting}


Geisinger providers (physicians and advanced practitioners) serve a network of 138 primary and specialty clinic sites including 79 communitybased primary care clinics in Pennsylvania. Most of these clinics are based in the northeast and central region of Geisinger coverage, but some are in the western region of Pennsylvania.

\section{Study design}

Guided by the Conceptual Model of Implementation Research $(5,6)$, we conducted an evaluation of a pharmacist-led educational program on evidence-based practices for medication reconciliation by examining implementation outcomes. This study was approved by the Geisinger Institutional Review Board.

\section{Medication Reconciliation Educational Program}

To improve medication reconciliation practices in our ambulatory care clinics, we developed an educational program designed to be delivered to clinic personnel over a total of four sessions. The content was developed by an existing workgroup within our health system, the Ambulatory Medication Reconciliation and Education subgroup, which was tasked by system leaders with improving medication reconciliation. The workgroup consisted of pharmacists, nurses, and clinical leadership. The workgroup met monthly to discuss issues related to medication reconciliation. Led by two medication reconciliation champions, the educational materials were developed collaboratively by members of the workgroup. The materials drew on both existing literature on best practices, clinical experiences of members, and a needs assessment performed by the study team (7-9). Specifically, the educational program highlighted several practices which are consistent with a comprehensive medication reconciliation including: 1) use open ended questions, 2) clarify and/or determine pharmacy used by the patient, 3) ask the patient about their current medications, 4) have the patient state the medication, strength, dose and how they take each medication, 5) ask for clarification if their response differs from the list in the electronic health record, 6) ask about non-prescription medications the patient is taking, and 7) evaluate medication adherence.

Once the training was developed, members of the workgroup trained pharmacists to deliver the education as part of an annual professional development retreat. The training and other relevant materials were made available through an internal website. The trained pharmacists, who were embedded within primary and specialty care clinics at Geisinger, trained other clinical staff on how to complete a proper medication reconciliation over 4 weeks in 10-15-minute sessions using a combination of presentations and example videos of good and bad medication reconciliations. Implementation strategies with specifications are available in Table 1 following guidance for specifying and reporting of implementation strategies by Proctor and colleagues (10). 
Table 1

Detailed descriptions of implementation strategies for an ambulatory medication reconciliation initiative

\begin{tabular}{|c|c|c|c|c|c|}
\hline \multirow{2}{*}{$\begin{array}{l}\text { Domain } \\
\text { Name it }\end{array}$} & \multicolumn{5}{|c|}{ Description of implementation strategies } \\
\hline & $\begin{array}{l}\text { Identify and prepare } \\
\text { champions }\end{array}$ & Develop educational materials & $\begin{array}{l}\text { Distribute } \\
\text { educational } \\
\text { materials }\end{array}$ & $\begin{array}{l}\text { Use train the trainer } \\
\text { strategies }\end{array}$ & $\begin{array}{l}\text { Conduct } \\
\text { educational } \\
\text { outreach visits }\end{array}$ \\
\hline Define it & $\begin{array}{l}\text { System leadership } \\
\text { identified, prepared, and } \\
\text { created a workgroup of } \\
\text { medication reconciliation } \\
\text { experts to focus on } \\
\text { improving the medication } \\
\text { reconciliation process for } \\
\text { the healthcare system }\end{array}$ & $\begin{array}{l}\text { System medication } \\
\text { reconciliation workgroup } \\
\text { developed education materials } \\
\text { including videos and } \\
\text { presentations that will be } \\
\text { delivered over several sessions } \\
\text { to clinic personnel who } \\
\text { conduct medication } \\
\text { reconciliation }\end{array}$ & $\begin{array}{l}\text { Distribute } \\
\text { educational } \\
\text { materials via } \\
\text { shared website } \\
\text { (i.e. sharepoint) }\end{array}$ & $\begin{array}{l}\text { Train clinical } \\
\text { pharmacists to train } \\
\text { each clinic site on } \\
\text { evidence-based } \\
\text { medication } \\
\text { reconciliation } \\
\text { practices }\end{array}$ & $\begin{array}{l}\text { Pharmacists' } \\
\text { train clinic } \\
\text { personnel at } \\
\text { clinic sites }\end{array}$ \\
\hline \multicolumn{6}{|l|}{ Specify it } \\
\hline Actor(s) & System leadership & $\begin{array}{l}\text { Medication reconciliation } \\
\text { champions }\end{array}$ & $\begin{array}{l}\text { Medication } \\
\text { reconciliation } \\
\text { champions }\end{array}$ & $\begin{array}{l}\text { Medication } \\
\text { reconciliation } \\
\text { champions }\end{array}$ & $\begin{array}{l}\text { Pharmacists } \\
\text { (trainers) }\end{array}$ \\
\hline Action(s) & $\begin{array}{l}\text { Identify champions of the } \\
\text { medication reconciliation } \\
\text { committee }\end{array}$ & $\begin{array}{l}\text { Develop } 10-15 \text { minute in- } \\
\text { person (or virtual) educational } \\
\text { blasts to facilitate completion } \\
\text { of medication reconciliation at } \\
\text { every visit }\end{array}$ & $\begin{array}{l}\text { Develop } \\
\text { website to host } \\
\text { educational } \\
\text { material so } \\
\text { that it is } \\
\text { accessible by } \\
\text { all } \\
\text { stakeholders }\end{array}$ & $\begin{array}{l}\text { Pharmacists were } \\
\text { trained by medication } \\
\text { reconciliation } \\
\text { champions at } \\
\text { professional } \\
\text { development retreat } \\
\text { and we will train to } \\
\text { teach clinic personnel } \\
\text { at their clinic sites }\end{array}$ & $\begin{array}{l}\text { Educate clinic } \\
\text { personnel on } \\
\text { appropriate } \\
\text { medication } \\
\text { reconciliation } \\
\text { practices to } \\
\text { improve } \\
\text { medication } \\
\text { records in the } \\
\text { EHR }\end{array}$ \\
\hline $\begin{array}{l}\text { Target(s) of } \\
\text { the action }\end{array}$ & $\begin{array}{l}\text { Medication reconciliation } \\
\text { champions }\end{array}$ & $\begin{array}{l}\text { Clinic personnel performing } \\
\text { medication reciliation in } \\
\text { ambulatory care clinics }\end{array}$ & $\begin{array}{l}\text { Pharmacist at } \\
\text { each site that } \\
\text { will educate the } \\
\text { clinic personnel } \\
\text { on evidence- } \\
\text { based } \\
\text { medication } \\
\text { reconciliation } \\
\text { techniques }\end{array}$ & Pharmacists & $\begin{array}{l}\text { Any clinic } \\
\text { personnel that } \\
\text { conduct } \\
\text { medication } \\
\text { reconciliations }\end{array}$ \\
\hline Temporality & $\begin{array}{l}\text { Prior to any medication } \\
\text { reconciliation program } \\
\text { development }\end{array}$ & $\begin{array}{l}\text { Prior to roll-out of the } \\
\text { pharmacist educational } \\
\text { program determine who will be } \\
\text { the trainers (train the trainer } \\
\text { education strategy) }\end{array}$ & $\begin{array}{l}\text { After the } \\
\text { development of } \\
\text { the educational } \\
\text { materials but } \\
\text { prior to the } \\
\text { training of } \\
\text { pharmacists } \\
\text { and clinic site } \\
\text { training }\end{array}$ & $\begin{array}{l}\text { After development and } \\
\text { distribution of } \\
\text { educational materials } \\
\text { but before educational } \\
\text { outreach at clinic sites }\end{array}$ & $\begin{array}{l}\text { Education will } \\
\text { start after the } \\
\text { educational } \\
\text { materials are } \\
\text { developed }\end{array}$ \\
\hline Dose & $\begin{array}{l}\text { As needed, the } \\
\text { designation of the } \\
\text { champions was } \\
\text { reassessed }\end{array}$ & $\begin{array}{l}\text { Modifications were made to } \\
\text { the training materials as } \\
\text { needed }\end{array}$ & $\begin{array}{l}\text { Modifications } \\
\text { were made to } \\
\text { the training } \\
\text { materials as } \\
\text { needed }\end{array}$ & Once & $\begin{array}{l}\text { 10-15-minute } \\
\text { presentations } \\
\text { for } 4 \text { weeks } \\
\text { and } \\
\text { competency } \\
\text { annually and } \\
\text { new hire } \\
\text { training }\end{array}$ \\
\hline
\end{tabular}

\section{Data collection}

Implementation outcomes measured include penetration, fidelity, acceptability, appropriateness, feasibility, and adoption. Table 2 describes the study specific definition, measurement, and data source for each implementation outcome. Data was collected through direct observations, administrative data, pre- and post-surveys, and semi-structured interviews. 
Table 2

Definition, measurement, and data source for implementation outcomes studies

\begin{tabular}{|c|c|c|c|}
\hline $\begin{array}{l}\text { Implementation } \\
\text { outcome }\end{array}$ & Definition & Measurement & Data source \\
\hline \multirow[t]{4}{*}{ Penetration } & \multirow[t]{4}{*}{$\begin{array}{l}\text { Penetration of the Medication Reconciliation } \\
\text { Educational Program to Clinic Sites }\end{array}$} & - How many sites participated in the training? & \multirow[t]{4}{*}{$\begin{array}{l}\text { - Administrative } \\
\text { data }\end{array}$} \\
\hline & & $\begin{array}{l}\text { - Of those sites, how many healthcare staff should } \\
\text { have attended the training? }\end{array}$ & \\
\hline & & - How many staff were we able to train? & \\
\hline & & $\begin{array}{l}\text { - How many staff completed the entire training } \\
\text { versus a portion of the training? }\end{array}$ & \\
\hline \multirow[t]{2}{*}{ Fidelity } & \multirow{2}{*}{$\begin{array}{l}\text { Fidelity of the Pharmacist to Deliver the } \\
\text { Medication Reconciliation Educational } \\
\text { Program as Designed }\end{array}$} & $\begin{array}{l}\text { - The degree to which the pharmacists were able to } \\
\text { implement the educational program as intended }\end{array}$ & $\begin{array}{l}\text { - Administrative } \\
\text { data }\end{array}$ \\
\hline & & - Adaptations that were made & $\begin{array}{l}\text { - Semi- } \\
\text { structured } \\
\text { interviews with } \\
\text { pharmacists }\end{array}$ \\
\hline \multirow[t]{2}{*}{ Acceptability } & \multirow[t]{2}{*}{$\begin{array}{l}\text { Acceptability of the Medication Reconciliation } \\
\text { Educational Program by Clinic Personnel }\end{array}$} & & \multirow{2}{*}{$\begin{array}{l}\text { - Pre- and post- } \\
\text { surveys } \\
\text { - Semi- } \\
\text { structured } \\
\text { interviews with } \\
\text { clinic personnel }\end{array}$} \\
\hline & & - Knowledge gained from educational program & \\
\hline Appropriateness & $\begin{array}{l}\text { Appropriateness of the Medication } \\
\text { Reconciliation Educational Program by Clinic } \\
\text { Personnel }\end{array}$ & $\begin{array}{l}\text { - Relevance of the education program to staff's } \\
\text { current practice }\end{array}$ & $\begin{array}{l}\text { - Semi- } \\
\text { structured } \\
\text { interviews with } \\
\text { clinic personnel }\end{array}$ \\
\hline \multirow[t]{2}{*}{ Feasibility } & \multirow[t]{2}{*}{$\begin{array}{l}\text { Feasibility to Implement the Medication } \\
\text { Reconciliation Skills from the Educational } \\
\text { Program into Practice by the Clinic Personnel }\end{array}$} & $\begin{array}{l}\text { - Extent to which the skills from the educational } \\
\text { program were deployed at the clinic sites }\end{array}$ & \multirow{2}{*}{$\begin{array}{l}\text { - Semi- } \\
\text { structured } \\
\text { interviews with } \\
\text { clinic personnel }\end{array}$} \\
\hline & & $\begin{array}{l}\text { - Did staff think the steps to complete an evidence- } \\
\text { based medication reconciliation was practical to } \\
\text { implement into their workflow in clinic? }\end{array}$ & \\
\hline Adoption & $\begin{array}{l}\text { Adoption of the Medication Reconciliation } \\
\text { Skills from the Educational Program into } \\
\text { Practice by the Clinic Personnel }\end{array}$ & $\begin{array}{l}\text { - How many staff implemented the steps to } \\
\text { complete an evidence-based medication } \\
\text { reconciliation in practice? }\end{array}$ & $\begin{array}{l}\text { - Direct } \\
\text { observations of } \\
\text { clinic personnel }\end{array}$ \\
\hline
\end{tabular}

Direct observations. We conducted direct observations of patient encounters at three primary care clinics across Geisinger in June of 2021 . The clinics, staff, and encounters observed were chosen through convenience sampling in consultation with clinic leadership. The purpose of the direct observations was to measure one implementation outcome: adoption (uptake of the educational program). Adoption was measured using a structured observation guide (Additional File 1) which focused on behaviors which facilitate a proper medication reconciliation. These behaviors were chosen based on the educational training at each site. The direct observations were conducted by medical students on a summer internship.

Pre- and Post-Surveys. We conducted pre- and post-surveys of clinic personnel to explore acceptability and knowledge gained about medication reconciliation before and after deployment of the educational program. Working with clinical leadership and pharmacists hosting the training, we identified clinic personnel working in ambulatory clinic sites who were expected to receive the educational strategy, then invited these clinic personnel to participate in a pre-training survey via e-mail. Clinic personnel included physicians, advanced practitioners, nurses, medical assistants, case managers, and community health assistants. The pre-survey had 12-questions consisting of 7 demographic and 5 knowledge and satisfaction questions. After the training we sent a post-survey to these same clinic sites. The post-survey had 16 -questions consisting of 8 demographics questions and 8 knowledge and satisfaction questions. Based on pilot testing, completion of both surveys should have taken no more than 5 minutes. Both surveys were administered using Research Electronic Data Capture, or REDCap (REDCap, Nashville, Tennessee), a secure web application for building and managing surveys online and databases $(11,12)$. We sent out one reminder e-mail two days after the initial surveys were sent, and staff received $\$ 10$ e-gift cards for each survey completed.

Semi-structured interviews. We conducted interviews with the pharmacists who delivered the educational program and clinical personnel that attended the educational program on medication reconciliation to understand their perspectives on, and experience with, the educational program. Specifically, we assessed the following implementation outcomes: acceptability, appropriateness, and feasibility for clinic personnel 
who received the educational program and fidelity of the pharmacists for the delivery of the educational program. Participants included physicians, nurses, and medical assistants. All clinic personnel were recruited using purposive sampling via e-mail. The pharmacists were recruited if they performed at least one training and the clinic personnel were recruited if they attended at least one session of the medication reconciliation trainings at their clinic site. We conducted all interviews using a semi-structured interview guide (Additional File 2). Example questions included: Tell me what your thoughts about the medication reconciliation training were; How could the training be improved?; How did it help you perform an improve medication reconciliation with patients?, among other questions. The individual semi-structured interviews were conducted by an experienced qualitative researcher (LKJ or KMR) and lasted up to 30 minutes. Staff received a \$25 e-gift card for participating.

\section{Data analysis}

Direct observations. Data from the direct observations were handwritten by observers then manually inserted into a REDCap survey created by a member of the study team. Data were summarized using descriptive statistics with STATA 14.1 (StataCorp, College Station, TX) software. We also reviewed quantitative data for relationships between variables (e.g. between staff type and adherence to behaviors).

Pre- and Post-Surveys. Descriptive statistics (e.g., counts, percentages, means) were used to summarize the data. When performing a hypothesis test to look for differences in baseline characteristics or responses between groups, a chi-squared test was used when comparing percentages (unless there are less than 5 of a particular response, in which case Fisher's exact test was used instead), and a Student's t-test was used when comparing means of continuous variables. All analyses were performed using SAS 9.4 (SAS Institute, Cary, NC) with p<0.05 considered significant.

Semi-structured interviews. Directly after each interview, a summary of the discussion was created, and responses were mapped to the appropriate implementation outcomes of interest. The interviews were audio recorded and transcribed verbatim using the transcription service offered by our institution. A member of the research team (VD) reviewed and de-identified the transcripts, then the transcripts were checked for accuracy by two members of the research team (LKJ and VD). A rapid qualitative analysis method was deployed; research staff reviewed interview summaries for important outcomes and then reviewed transcriptions for accuracy and supportive quotations (13).

\section{Results}

\section{Penetration of the Medication Reconciliation Educational Program to Clinic Sites}

A total of 37/46 (80\%) primary care sites implemented the pharmacist delivered medication reconciliation education from April to June 2021 with equal representation from each of Geisinger's regions during the study observations period. Of the 684 clinical personnel that were eligible for the education, $59 \%$ completed the entire education over the 4 weeks (or a modified version) and $81 \%$ completed a portion of the education. Eight sites achieved $100 \%$ attendance of clinical personnel. Site-level demographics and education delivery information is available in Table 3. 
Table 3

Site Demographics and Participation in Medication Reconciliation Educational Program

\begin{tabular}{|c|c|c|c|c|c|c|c|c|c|c|}
\hline Site & Region & $\begin{array}{l}\text { Practice } \\
\text { type }\end{array}$ & $\begin{array}{l}\text { Delivery } \\
\text { of } \\
\text { education }\end{array}$ & $\begin{array}{l}\text { Number } \\
\text { of weeks } \\
\text { of } \\
\text { education }\end{array}$ & $\begin{array}{l}\text { Adaptations } \\
\text { made to } \\
\text { timing } \\
\text { format of } \\
\text { the } \\
\text { education }\end{array}$ & $\begin{array}{l}\text { Number } \\
\text { of clinical } \\
\text { personnel } \\
\text { identified } \\
\text { as } \\
\text { eligible } \\
\text { for } \\
\text { training }\end{array}$ & $\begin{array}{l}\text { Number } \\
\text { of clinical } \\
\text { personnel } \\
\text { present } \\
\text { for the } \\
\text { entire } \\
\text { training }\end{array}$ & $\begin{array}{l}\text { Percentage } \\
\text { of clinical } \\
\text { staff that } \\
\text { completed } \\
\text { entire } \\
\text { training }\end{array}$ & $\begin{array}{l}\text { Number } \\
\text { of clinical } \\
\text { personnel } \\
\text { present } \\
\text { for at } \\
\text { least one } \\
\text { training }\end{array}$ & $\begin{array}{l}\text { Percentage } \\
\text { of clinical } \\
\text { staff that } \\
\text { completed } \\
\text { partial } \\
\text { training (at } \\
\text { least one } \\
\text { session) }\end{array}$ \\
\hline 1 & Central & Primary & Virtual & 3 & $Y$ & 23 & 7 & $\begin{array}{l}7 / 23 \\
(30.4 \%)\end{array}$ & 15 & $\begin{array}{l}15 / 23 \\
(65.2 \%)\end{array}$ \\
\hline 9 & Central & Primary & In-Person & 3 & $\mathrm{Y}$ & 5 & 2 & $\begin{array}{l}2 / 5 \\
(40.0 \%)\end{array}$ & 5 & $100 \%$ \\
\hline 13 & Central & Primary & Virtual & 2 & $Y$ & 6 & 4 & $\begin{array}{l}4 / 6 \\
(66.7 \%)\end{array}$ & 5 & $\begin{array}{l}5 / 6 \\
(83.3 \%)\end{array}$ \\
\hline 15 & Central & Primary & Virtual & 4 & $\mathrm{Y}$ & 5 & 5 & $100 \%$ & 5 & $100 \%$ \\
\hline 16 & Central & Primary & In-Person & 4 & $\mathrm{~N}$ & 4 & 4 & $100 \%$ & 4 & $100 \%$ \\
\hline 18 & Central & Primary & In-Person & 3 & $\mathrm{Y}$ & 20 & 12 & $\begin{array}{l}12 / 20 \\
(60.0 \%)\end{array}$ & 19 & $\begin{array}{l}19 / 20 \\
(95.0 \%)\end{array}$ \\
\hline 19 & Central & Primary & In-Person & 2 & $\mathrm{Y}$ & 13 & 6 & $\begin{array}{l}6 / 13 \\
(46.2 \%)\end{array}$ & 11 & $\begin{array}{l}11 / 13 \\
(84.6 \%)\end{array}$ \\
\hline 22 & Central & Primary & In-Person & 1 & $\mathrm{Y}$ & 8 & 8 & $100 \%$ & 8 & $100 \%$ \\
\hline 24 & Central & Primary & In-Person & 2 & $\mathrm{Y}$ & 9 & 8 & $\begin{array}{l}8 / 9 \\
(88.9 \%)\end{array}$ & 8 & $\begin{array}{l}8 / 9 \\
(88.9 \%)\end{array}$ \\
\hline 27 & Central & Primary & Virtual & 2 & $\mathrm{Y}$ & 6 & 4 & $\begin{array}{l}4 / 6 \\
(66.7 \%)\end{array}$ & 6 & $100 \%$ \\
\hline 29 & Central & Primary & Virtual & 1 & $Y$ & 12 & 9 & $\begin{array}{l}9 / 12 \\
(75.0 \%)\end{array}$ & 9 & $\begin{array}{l}9 / 12 \\
(75.0 \%)\end{array}$ \\
\hline 35 & Central & Primary & In-Person & 1 & $\mathrm{Y}$ & 7 & 4 & $\begin{array}{l}4 / 7 \\
(57.1 \%)\end{array}$ & 4 & $\begin{array}{l}4 / 7 \\
(57.1 \%)\end{array}$ \\
\hline 36 & Central & Primary & In-Person & 1 & $Y$ & 25 & 10 & $\begin{array}{l}10 / 25 \\
(40.0 \%)\end{array}$ & 10 & $\begin{array}{l}10 / 25 \\
(40.0 \%)\end{array}$ \\
\hline 37 & Central & Primary & In-Person & 1 & $\mathrm{Y}$ & 10 & 9 & $\begin{array}{l}9 / 10 \\
(90.0 \%)\end{array}$ & 9 & $\begin{array}{l}9 / 10 \\
(90.0 \%)\end{array}$ \\
\hline 4 & Northeast & Primary & Mix & 4 & $\mathrm{Y}$ & 28 & 4 & $\begin{array}{l}4 / 28 \\
(14.3 \%)\end{array}$ & 19 & $\begin{array}{l}19 / 28 \\
(67.9 \%)\end{array}$ \\
\hline 6 & Northeast & Primary & Mix & 3 & $\mathrm{Y}$ & 62 & 5 & $\begin{array}{l}5 / 62 \\
(8.1 \%)\end{array}$ & 20 & $\begin{array}{l}20 / 62 \\
(32.3 \%)\end{array}$ \\
\hline 7 & Northeast & Primary & In-Person & 4 & $\mathrm{~N}$ & 8 & 7 & $\begin{array}{l}7 / 8 \\
(87.5 \%)\end{array}$ & 8 & $100 \%$ \\
\hline 8 & Northeast & Primary & In-Person & 4 & $\mathrm{~N}$ & 32 & 2 & $\begin{array}{l}2 / 32 \\
(6.3 \%)\end{array}$ & 20 & $\begin{array}{l}20 / 32 \\
(62.5 \%)\end{array}$ \\
\hline 12 & Northeast & Primary & In-Person & 4 & $\mathrm{~N}$ & 3 & 3 & $100 \%$ & 3 & $100 \%$ \\
\hline 17 & Northeast & Primary & In-Person & 4 & $\mathrm{~N}$ & 22 & 1 & $\begin{array}{l}1 / 22 \\
(4.5 \%)\end{array}$ & 12 & $\begin{array}{l}12 / 22 \\
(54.5 \%)\end{array}$ \\
\hline 20 & Northeast & Primary & In-Person & 4 & $\mathrm{~N}$ & 5 & 4 & $\begin{array}{l}4 / 5 \\
(80.0 \%)\end{array}$ & 4 & $\begin{array}{l}4 / 5 \\
(80.0 \%)\end{array}$ \\
\hline \multirow[t]{2}{*}{21} & Northeast & Primary & Virtual & 2 & $Y$ & 10 & 10 & $100 \%$ & 10 & $100 \%$ \\
\hline & & & & 1 & & 8 & 8 & $100 \%$ & 8 & $100 \%$ \\
\hline 23 & Northeast & Primary & In-Person & 4 & $\mathrm{~N}$ & 7 & - & - & - & - \\
\hline 25 & Northeast & Primary & In-Person & 4 & $\mathrm{~N}$ & 11 & 2 & $\begin{array}{l}2 / 11 \\
(18.2 \%)\end{array}$ & 10 & $\begin{array}{l}10 / 11 \\
(90.9 \%)\end{array}$ \\
\hline
\end{tabular}




\begin{tabular}{|c|c|c|c|c|c|c|c|c|c|c|}
\hline Site & Region & $\begin{array}{l}\text { Practice } \\
\text { type }\end{array}$ & $\begin{array}{l}\text { Delivery } \\
\text { of } \\
\text { education }\end{array}$ & $\begin{array}{l}\text { Number } \\
\text { of weeks } \\
\text { of } \\
\text { education }\end{array}$ & $\begin{array}{l}\text { Adaptations } \\
\text { made to } \\
\text { timing } \\
\text { format of } \\
\text { the } \\
\text { education }\end{array}$ & $\begin{array}{l}\text { Number } \\
\text { of clinical } \\
\text { personnel } \\
\text { identified } \\
\text { as } \\
\text { eligible } \\
\text { for } \\
\text { training }\end{array}$ & $\begin{array}{l}\text { Number } \\
\text { of clinical } \\
\text { personnel } \\
\text { present } \\
\text { for the } \\
\text { entire } \\
\text { training }\end{array}$ & $\begin{array}{l}\text { Percentage } \\
\text { of clinical } \\
\text { staff that } \\
\text { completed } \\
\text { entire } \\
\text { training }\end{array}$ & $\begin{array}{l}\text { Number } \\
\text { of clinical } \\
\text { personnel } \\
\text { present } \\
\text { for at } \\
\text { least one } \\
\text { training }\end{array}$ & $\begin{array}{l}\text { Percentage } \\
\text { of clinical } \\
\text { staff that } \\
\text { completed } \\
\text { partial } \\
\text { training (at } \\
\text { least one } \\
\text { session) }\end{array}$ \\
\hline 26 & Northeast & Primary & In-Person & 1 & Y & 22 & 8 & $\begin{array}{l}8 / 22 \\
(36.4 \%)\end{array}$ & 8 & $\begin{array}{l}8 / 22 \\
(36.4 \%)\end{array}$ \\
\hline 38 & Northeast & Primary & Virtual & 1 & Y & 15 & 12 & $\begin{array}{l}12 / 15 \\
(80.0 \%)\end{array}$ & 12 & $\begin{array}{l}12 / 15 \\
(80.0 \%)\end{array}$ \\
\hline 3 & West & Primary & In-Person & 3 & $Y$ & 27 & 8 & $\begin{array}{l}8 / 27 \\
(29.6 \%)\end{array}$ & 22 & $\begin{array}{l}22 / 27 \\
(81.5 \%)\end{array}$ \\
\hline 5 & West & Primary & In-Person & 4 & $N$ & 6 & 1 & $\begin{array}{l}1 / 6 \\
(16.7 \%)\end{array}$ & 6 & $100 \%$ \\
\hline 10 & West & Primary & In-Person & 4 & $\mathrm{~N}$ & 16 & - & - & - & - \\
\hline 14 & West & Primary & Virtual & 4 & Y & 10 & 1 & $\begin{array}{l}1 / 10 \\
(10.0 \%)\end{array}$ & 10 & $100 \%$ \\
\hline 30 & West & Primary & Virtual & 1 & Y & 37 & 22 & $\begin{array}{l}22 / 37 \\
(59.5 \%)\end{array}$ & 22 & $\begin{array}{l}22 / 37 \\
(59.5 \%)\end{array}$ \\
\hline 31 & West & Primary & Virtual & 1 & Y & 6 & 6 & $100 \%$ & 6 & $100 \%$ \\
\hline 32 & West & Primary & Virtual & 1 & Y & 19 & 13 & $\begin{array}{l}13 / 19 \\
(68.4 \%)\end{array}$ & 13 & $\begin{array}{l}13 / 19 \\
(68.4 \%)\end{array}$ \\
\hline 33 & West & Primary & Virtual & 1 & Y & 6 & 6 & $100 \%$ & 6 & $100 \%$ \\
\hline 34 & West & Primary & Virtual & 4 & Y & 22 & 3 & $\begin{array}{l}3 / 22 \\
(13.6 \%)\end{array}$ & 15 & $\begin{array}{l}15 / 22 \\
(68.2 \%)\end{array}$ \\
\hline 39 & West & Primary & Virtual & 3 & Y & 29 & 10 & $\begin{array}{l}10 / 29 \\
(34.5 \%)\end{array}$ & 19 & $\begin{array}{l}19 / 29 \\
(65.5 \%)\end{array}$ \\
\hline 28 & All & Primary & Virtual & 1 & Y & 100 & 70 & $\begin{array}{l}70 / 100 \\
(70.0 \%)\end{array}$ & 70 & $\begin{array}{l}70 / 100 \\
(70.0 \%)\end{array}$ \\
\hline 11 & Central & Specialty & In-Person & 1 & Y & 6 & 5 & $\begin{array}{l}5 / 6 \\
(83.3 \%)\end{array}$ & 5 & $\begin{array}{l}5 / 6 \\
(83.3 \%)\end{array}$ \\
\hline 2 & West & Specialty & In-Person & 3 & Y & 7 & 5 & $\begin{array}{l}5 / 7 \\
(71.4 \%)\end{array}$ & 6 & $\begin{array}{l}6 / 7 \\
(85.7 \%)\end{array}$ \\
\hline
\end{tabular}

\section{Fidelity of the Pharmacist to Deliver the Medication Reconciliation Educational Program as Designed}

The initial implementation of the educational program targeted primary care clinics; however, 2 specialty clinics also implemented the program. Of the 37 primary care clinics, 10 (27\%) completed the medication reconciliation educational program as originally designed and 27 (73\%) made some adaptation to the delivery of the program. Adaptations were minor and consisted of consolidation of the educational program into fewer sessions, more frequent sessions to complete the training sooner (e.g.,1 day or 2-3 week programs), or splitting the educational program to target one type of medical personnel at a time (for example, prescribers at one meeting and nurses and medical assistants at another). Other adaptations included hosting the program virtually. A majority $(20 / 37,54 \%)$ of the sites hosted the education in-person while $41 \%$ (15/37) held virtual education sessions and $5 \%(2 / 37)$ had a mix of both. These adaptations were made to meet the needs of their individual clinics and clinic personnel.

Interviews were completed with 11 clinic personnel who attended the educational program and 4 pharmacists that delivered the educational program. Detailed demographics for the interviews are available in Table 4. 
Table 4

Demographics of survey and semi-structured interview participants

\begin{tabular}{|c|c|c|c|c|}
\hline & $\begin{array}{l}\text { Pre-survey } \\
(n=296)\end{array}$ & $\begin{array}{l}\text { Post-survey } \\
(n=178)\end{array}$ & P-value & $\begin{array}{l}\text { Interview } \\
(n=15)\end{array}$ \\
\hline Male, N (\%) & $41(14 \%)$ & $23(13 \%)$ & 0.83 & $1(7 \%)$ \\
\hline Age, N (\%) & & & 0.85 & \\
\hline $18-40$ & $129(44 \%)$ & $73(41 \%)$ & & $9(60 \%)$ \\
\hline $40-60$ & $130(44 \%)$ & $81(46 \%)$ & & $3(20 \%)$ \\
\hline 60 and older & $37(13 \%)$ & $24(13 \%)$ & & $3(20 \%)$ \\
\hline Practice area, N (\%) & & & 0.37 & \\
\hline Primary Care & $276(93 \%)$ & $162(91 \%)$ & & $14(93 \%)$ \\
\hline Specialty Care & $20(7 \%)$ & $16(9 \%)$ & & $1(7 \%)$ \\
\hline Position type, N (\%) & & & 0.29 & \\
\hline Physician, PA, CRNP & $90(30 \%)$ & $44(25 \%)$ & & $3(20 \%)$ \\
\hline Nurse (RN/LPN) & $131(44 \%)$ & $79(44 \%)$ & & $6(40 \%)$ \\
\hline Pharmacist & - & - & & $4(27 \%)$ \\
\hline Medical assistants & $34(11 \%)$ & $29(16 \%)$ & & $2(13 \%)$ \\
\hline Case manager & $26(9 \%)$ & $21(12 \%)$ & & - \\
\hline Community health assistants & $2(1 \%)$ & $0(0 \%)$ & & - \\
\hline Other & $13(4 \%)$ & $5(3 \%)$ & & - \\
\hline Average number of years in practice & $9.3(10.5)$ & $8.5(9.3)$ & 0.35 & - \\
\hline Mean (SD) & $5(2,14)$ & $4(2,14)$ & & \\
\hline \multicolumn{5}{|l|}{ Median (IQR) } \\
\hline Number of clinics participating & 39 & 36 & - & 12 \\
\hline Completed training, N (\%) & - & $123(69 \%)$ & - & - \\
\hline All sessions & & $35(31 \%)$ & & \\
\hline Some, but not all sessions & & & & \\
\hline
\end{tabular}

Pharmacists felt the educational program was generally well-received and stimulated good discussion at the clinic sites. Discussion was noted to be more difficult at the clinics which held their training virtually. In addition, the pharmacists were not always able to reach the target group of clinic personnel due to busy schedules, prior engagements, or trainings held over the lunch hour. Pharmacists emphasized how the educational program needs to be ongoing to ensure that everyone is keeping up with new technologies and changes in the electronic health record that affect the medication reconciliation process. Exemplar quotations from pharmacists related to fidelity to the educational program are listed below.

"I guess maybe timewise, just the clinic being too big, not enough time to hit all of the people that you need to. I know with some of the huddles you don't always have every person there, they come and go. There are some people that just never attended a huddle and that was just in the bigger clinics, so you'd miss some. So, just having the time to actually do it." (106 Pharmacist)

"We have all different sorts of specialties here. So, instead of doing it in the weekly increments, just because there are so many providers that are here and they're all here different days, different hours, I presented it to all the nursing staff early morning on a Thursday. All the nursing staff that deals with all the providers collectively. Gave them all separate power points, and we reviewed it together, one by one, and as a whole in one sitting." (358 Pharmacist)

"From 1:10 to 1:40 is now considered "lunch" for our providers so they don't typically have patients and nursing a lot of times will kind of start to eat lunch around noon, but a lot of them will kind of peace out during that timeframe because of the fact that there are no providers to be rooming for and there is just a little bit more time, so all of nursing wasn't always able to attend." (696 Pharmacist) 


\section{Acceptability of the Medication Reconciliation Educational Program by Clinic Personnel}

A total of 296 clinic personnel completed the pre-survey, while 178 completed the post-survey. There were no statistically significant differences in baseline characteristics between clinic personnel that completed the surveys. Detailed demographics for the pre- and post-survey are available in Table 4.

The pre- and post-surveys explored clinic personnel acceptability and knowledge regarding the educational program on medication reconciliation (Table 5). When asked to indicate their agreement with the following statement, "I am confident that I complete medication reconciliation correctly most of the time," the percentage of clinic personnel responding "strongly disagree" increased by $5 \%(2 \%$ vs. $7 \%, p=0.01)$ and the percentage responding "strongly agree" increased by $11 \%(33 \%$ vs. $44 \%, p=0.02)$ from the pre- to the post-survey. Thus, the educational program 'polarized' people and made them either more or less confident, with fewer people in the middle. For every category of product (except prescription medications, creams/ointments, eye drops, and "none"), there were statistically significant increases in the percentages of clinic personnel saying those products were important to include in medication reconciliation. There was also a statistically significant increase in clinic personnel correctly selecting the most appropriate behavior consistent with a medication reconciliation, which changed from $78 \%$ presurvey to $91 \%$ post-survey $(p=0.0003)$. While post-survey respondents were also more likely than pre-survey respondents to state that improper medication reconciliation can result in admissions or readmissions ( $96 \%$ vs. $90 \%, p=0.02)$, a correct answer, they were also more likely to state that an improper medication reconciliation may lead to loss of insurance coverage, an incorrect answer $(42 \%$ vs. $28 \%, p=0.002)$. Clinic personnel felt they learned something from the educational program that would apply to their work ( $86 \%$ said agree or strongly agree), and were likely to recommend the program to a friend (on the Net Promoter Scale of 0-10, mean response was 8.2). 
Table 5

Clinic personnel pre- and post-survey responses

\begin{tabular}{|c|c|c|c|c|}
\hline Questions & Responses & $\begin{array}{l}\begin{array}{l}\text { Pre- } \\
\text { survey } \\
\text { results }\end{array} \\
(n= \\
296)\end{array}$ & $\begin{array}{l}\text { Post- } \\
\text { survey } \\
\text { results } \\
(n=178)\end{array}$ & $\begin{array}{l}\text { P- } \\
\text { value }\end{array}$ \\
\hline \multirow{5}{*}{$\begin{array}{l}\text { Please indicate your agreement or disagreement with the } \\
\text { following statement: I am confident that I complete } \\
\text { medication reconciliation correctly almost all the time. }\end{array}$} & Strongly disagree & $6(2 \%)$ & $12(7 \%)$ & \multirow[t]{5}{*}{0.002} \\
\hline & Disagree & $\begin{array}{l}10 \\
(3 \%)\end{array}$ & $2(1 \%)$ & \\
\hline & Neither agree nor disagree & $\begin{array}{l}32 \\
(11 \%)\end{array}$ & $10(6 \%)$ & \\
\hline & Agree & $\begin{array}{l}151 \\
(51 \%)\end{array}$ & $76(43 \%)$ & \\
\hline & Strongly agree & $\begin{array}{l}97 \\
(33 \%)\end{array}$ & $78(44 \%)$ & \\
\hline \multirow{6}{*}{$\begin{array}{l}\text { Medication reconciliation is the process of ensuring that a } \\
\text { patient's medication list is complete and accurate. This } \\
\text { process includes... (correct answer in bold) }\end{array}$} & $\begin{array}{l}\text { Collecting information from the patient and } \\
\text { other sources }\end{array}$ & $0(0 \%)$ & $0(0 \%)$ & \multirow[t]{6}{*}{0.45} \\
\hline & $\begin{array}{l}\text { Comparing that information to information } \\
\text { held by the health system (typically in the } \\
\text { electronic health record) }\end{array}$ & $\begin{array}{l}2(< \\
1 \%)\end{array}$ & $1(<1 \%)$ & \\
\hline & $\begin{array}{l}\text { Reconciling any differences in medication } \\
\text { list }\end{array}$ & $\begin{array}{l}1(< \\
1 \%)\end{array}$ & $0(0 \%)$ & \\
\hline & $\mathrm{A}$ and $\mathrm{C}$ & $\begin{array}{l}2(< \\
1 \%)\end{array}$ & $0(0 \%)$ & \\
\hline & $A$ and $B$ & $\begin{array}{l}3(< \\
1 \%)\end{array}$ & $0(0 \%)$ & \\
\hline & All of the above & $\begin{array}{l}288 \\
(97 \%)\end{array}$ & $\begin{array}{l}177 \\
(99 \%)\end{array}$ & \\
\hline \multirow[t]{9}{*}{$\begin{array}{l}\text { What products are important to include when you perform } \\
\text { a medication reconciliation? (correct answers in bold) }\end{array}$} & Prescription medications & $\begin{array}{l}293 \\
(99 \%)\end{array}$ & $\begin{array}{l}177 \\
(99 \%)\end{array}$ & 0.99 \\
\hline & Over-the-counter medications & $\begin{array}{l}284 \\
(96 \%)\end{array}$ & $\begin{array}{l}177 \\
(99 \%)\end{array}$ & 0.04 \\
\hline & Herbal or dietary supplements & $\begin{array}{l}280 \\
(95 \%)\end{array}$ & $\begin{array}{l}176 \\
(99 \%)\end{array}$ & 0.02 \\
\hline & Creams/ointments & $\begin{array}{l}283 \\
(96 \%)\end{array}$ & $\begin{array}{l}176 \\
(99 \%)\end{array}$ & 0.05 \\
\hline & Eye drops & $\begin{array}{l}286 \\
(97 \%)\end{array}$ & $\begin{array}{l}177 \\
(99 \%)\end{array}$ & 0.06 \\
\hline & Lancets & $\begin{array}{l}248 \\
(84 \%)\end{array}$ & $\begin{array}{l}169 \\
(95 \%)\end{array}$ & 0.0003 \\
\hline & Glucose strips & $\begin{array}{l}255 \\
(86 \%)\end{array}$ & $\begin{array}{l}170 \\
(96 \%)\end{array}$ & 0.001 \\
\hline & Oxygen & $\begin{array}{l}265 \\
(90 \%)\end{array}$ & $\begin{array}{l}173 \\
(97 \%)\end{array}$ & 0.002 \\
\hline & None of the above & $\begin{array}{l}14 \\
(5 \%)\end{array}$ & $12(7 \%)$ & 0.35 \\
\hline \multirow[t]{3}{*}{$\begin{array}{l}\text { Select the most appropriate behavior consistent with a } \\
\text { medication reconciliation. (correct answer in bold) }\end{array}$} & $\begin{array}{l}\text { Ask them closed ended questions about their } \\
\text { medication use }\end{array}$ & $\begin{array}{l}14 \\
(5 \%)\end{array}$ & $9(5 \%)$ & \multirow[t]{3}{*}{0.0001} \\
\hline & $\begin{array}{l}\text { Read the medications on their electronic } \\
\text { health record to the patient }\end{array}$ & $\begin{array}{l}51 \\
(17 \%)\end{array}$ & $7(4 \%)$ & \\
\hline & $\begin{array}{l}\text { Ask them to tell you the name, dose, strength, } \\
\text { and how often they take their } \\
\text { medications and confirm with their } \\
\text { health record }\end{array}$ & $\begin{array}{l}231 \\
(78 \%)\end{array}$ & $\begin{array}{l}162 \\
(91 \%)\end{array}$ & \\
\hline
\end{tabular}




\begin{tabular}{|c|c|c|c|c|}
\hline Questions & Responses & $\begin{array}{l}\text { Pre- } \\
\text { survey } \\
\text { results } \\
(n= \\
296)\end{array}$ & 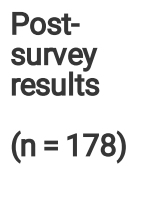 & $\begin{array}{l}\mathrm{P}- \\
\text { value }\end{array}$ \\
\hline \multirow[t]{4}{*}{$\begin{array}{l}\text { Improper medication reconciliation can result in... (correct } \\
\text { answers in bold) }\end{array}$} & Adverse events & $\begin{array}{l}288 \\
(97 \%)\end{array}$ & $\begin{array}{l}176 \\
(99 \%)\end{array}$ & 0.25 \\
\hline & Loss of insurance coverage & $\begin{array}{l}83 \\
(28 \%)\end{array}$ & $74(42 \%)$ & 0.002 \\
\hline & Admissions and/or re-admissions & $\begin{array}{l}265 \\
(90 \%)\end{array}$ & $\begin{array}{l}170 \\
(96 \%)\end{array}$ & 0.02 \\
\hline & Medication interactions & $\begin{array}{l}286 \\
(97 \%)\end{array}$ & $\begin{array}{l}176 \\
(99 \%)\end{array}$ & 0.23 \\
\hline \multirow{5}{*}{$\begin{array}{l}\text { Please indicate your agreement or disagreement with the } \\
\text { following statement: I learned something from the training } \\
\text { that I will apply to my work }\end{array}$} & Strongly disagree & & $13(7 \%)$ & \\
\hline & Disagree & & $4(2 \%)$ & \\
\hline & Neither agree nor disagree & & $9(5 \%)$ & \\
\hline & Agree & & $92(52 \%)$ & \\
\hline & Strongly agree & & $60(34 \%)$ & \\
\hline \multirow{13}{*}{$\begin{array}{l}\text { On a scale of } 0-10 \text {, how likely are you to recommend the } \\
\text { medication reconciliation training to a friend? }\end{array}$} & Mean (SD) & & $8.2(2.5)$ & \\
\hline & Individual scores, N (\%) & & $\begin{array}{l}\text { Individual } \\
\text { scores, } \mathrm{N} \\
(\%)\end{array}$ & \\
\hline & 0 & & $8(4 \%)$ & \\
\hline & 1 & & $0(0 \%)$ & \\
\hline & 2 & & $1(<1 \%)$ & \\
\hline & 3 & & $0(0 \%)$ & \\
\hline & 4 & & $3(2 \%)$ & \\
\hline & 5 & & $16(9 \%)$ & \\
\hline & 6 & & $2(1 \%)$ & \\
\hline & 7 & & $17(10 \%)$ & \\
\hline & 8 & & $31(17 \%)$ & \\
\hline & 9 & & $9(12 \%)$ & \\
\hline & 10 & & 78 (44\%) & \\
\hline
\end{tabular}

All clinic personnel interviewed felt satisfied with the educational program. Also, all described the program as informative and liked that it provided examples on how to complete the medication reconciliation within the electronic health record. About a third, mostly providers, felt there was no new information that they learned from the education but felt it was a good refresher on the topic of medication reconciliation. Other clinic personnel discussed new learnings from the education including: how to place in a note to the doctor about the medication reconciliation they conducted; making sure dose, frequency, time of day is recorded for each medication the patient is taking; adding reasons for when a medication has been discontinued; and learning how to add natural supplements to the medication list. Exemplar quotes about acceptability of the medication reconciliation educational program by clinic personnel are listed below.

"It was very informative because there were lots of things, I didn't know myself when I was doing med rec because usually, I would just flag them to be taken off instead of taking them off myself, that I could do that. I didn't know I had to put a reason every time I took one off." (538 Nurse)

"I'm doing it constantly now as far as cleaning up the med rec. I mean we always did make Med reconciliation but now we're actually cleaning up the med rec. We're going in, we're discontinuing the meds, we could use med list cleanup, there's those different dropdown options and such, so yes." (102 Nurse) 


\section{Appropriateness of the Medication Reconciliation Educational Program by Clinic Personnel}

All clinic personnel felt the educational program was appropriate because it directly impacted their job. Clinical personnel identified obtaining an accurate medication reconciliation as a very important part of their job. Many nurses discussed how taking a good medication reconciliation helps the prescriber understand what the patient is taking and helps make important decisions about care. Prescribers felt medication reconciliation was important to caring for their patients. Many felt it was appropriate to have refresher education on the medication reconciliation process at some determined point in time or as updates are made to the electronic health record, and to incorporate this type of education into new employee orientation. Exemplar quotes about appropriateness of the medication reconciliation educational program by clinic personnel are listed below.

"I would hope most staff members already know why, but being able to explain to the patient makes them feel more empowered and they're more open to increasing dialogue." (552 Medical assistant)

"I think it will be very helpful, especially with new hires, because I think that when you get a new hire, like I will be hiring some new nurses, I will be able to implement this in part of their training for beginners training because I think you need to mold them in the beginning and not do the shortcuts, and I think it will be better. It's just everybody has to stay on the same page." (274 Nurse)

\section{Feasibility to Implement the Medication Reconciliation Skills from the Educational Program into Practice by the Clinic Personnel}

Even though clinic personnel felt the educational program was acceptable and appropriate, two major concerns were discussed: lack of patient knowledge and lack of time. Clinic personnel discussed how many patients do not know the names, dose, frequency, or other important aspects of the medications they are taking. This lack of knowledge from the patient creates barriers to implementing the medication reconciliation process described in the educational program. Some personnel recommended patients bring in their bottles or make a list of their medications when they come to the office, but acknowledged it is difficult to achieve. Most clinic personnel also discussed some aspect of time which would impact them from taking a good and accurate medication reconciliation. Some felt they did not have time to determine what medications the patient was taking before the prescriber needed to see the patient. Exemplar quotes about feasibility of the medication reconciliation educational program by clinic personnel are listed below.

"It's hard to do with some patients because they don't even remember what they're taking, and they don't bring a list in, so it's hard to do some of these. For those I just leave a note for the doctor that I tried to do these, and the patient is not very cooperative with it." (538 Nurse)

"Yeah, so just having to go through and then, one, I don't see them in person, so I can't really have them bring their pills with them, they kind of tell me my blue pill, so it's a little bit difficult for me to discriminate which ones they're taking, and then just kind of going through, because you can like pull in from like outside sources, like trying to pull that in and stuff like that, so it can be little bit time consuming when I'm doing the telemedicine visits." (638 Physician)

"I think the patient gets in the way. They don't listen. They say they don't know what they're taking. They're on a pill pack. They don't bring in the pills, they don't bring in the pill pack label you know I think it's more patient related than it is anything else." (102 Nurse)

\section{Adoption of the Medication Reconciliation Skills from the Educational Program into Practice by the Clinic Personnel}

A total of 55 observations of nurses and medical assistants were completed across three of the larger ambulatory clinic sites for their adoption of their learnings from the educational program. We found the adherence rate to the elements of the medication reconciliation which were covered in the education program ranged from $0-95 \%$ (Table 6). There was no meaningful difference across the three sites where the observations were conducted. 
Table 6

Adherence to elements of the medication reconciliation educational program

\begin{tabular}{|c|c|}
\hline Elements of Medication Reconciliation & $\begin{array}{l}\text { Total } \\
n=55\end{array}$ \\
\hline Verified patient's identity & $52(95 \%)$ \\
\hline Verified allergies & $40(73 \%)$ \\
\hline Accessed patient's medical list & $52(95 \%)$ \\
\hline Verified preferred pharmacy & $50(91 \%)$ \\
\hline Discussed Mail Order Pharmacy as appropriate & $2 / 2(100 \%)$ \\
\hline Reviewed patient's medication list with the patient & $52(95 \%)$ \\
\hline Used 'go reconcile' button & $0(0 \%)$ \\
\hline Verify Patient's current medication & $52(95 \%)$ \\
\hline Are you using your medication as prescribed? (Dose, Route, Frequency, etc.) & $37(67 \%)$ \\
\hline Asked about new medication & $19(35 \%)$ \\
\hline Added new medication & $9 / 19(47 \%)$ \\
\hline Asked about discontinued medications & $28(51 \%)$ \\
\hline Removed old medications & $14 / 28(50 \%)$ \\
\hline Asked about held medication & $12(22 \%)$ \\
\hline Reason discussed for hold, if applicable & $2 / 12(17 \%)$ \\
\hline Marked as held & $8 / 12(67 \%)$ \\
\hline Deleted duplicates, if applicable & $3(5.4 \%)$ \\
\hline Asked about side effects (adverse medication reactions) & $3(5.4 \%)$ \\
\hline Documentation of reaction & $3 / 3(100 \%)$ \\
\hline Asked about adherence (forgetfulness, trouble taking, or cost) & $6(11 \%)$ \\
\hline Ask about over the counter medications & $20(36 \%)$ \\
\hline Asked about "as needed" medications & $32(58 \%)$ \\
\hline Asked about other concerns/questions & $1(1.8 \%)$ \\
\hline Make note to Physician, if applicable & $19(35 \%)$ \\
\hline Check mark as review & $50(91 \%)$ \\
\hline
\end{tabular}

\section{Discussion}

Our study examined the implementation outcomes associated with implementing an educational program to improve ambulatory medication reconciliation. We found the medication reconciliation educational program had high attendance at the targeted primary care clinics and pharmacists adapted the presentation delivery, but not the content, to meet the needs of the individual clinic sites. Recipients of the educational program found it to be acceptable and appropriate and feasible to implement the skills from the educational program into their daily practice. However, they expressed some concerns related to portions of the medication reconciliation process which were out of their control including time to conduct an accurate medication reconciliation and patients knowing the medications they were prescribed. Adoption of the process detailed in the educational program was variable and dependent on other factors including responses from patients.

Our findings from the implementation of a medication reconciliation educational program are similar to other programs in both ambulatory and hospital settings $(14,15)$. A hospital-based educational program found an increase in knowledge and self-efficacy for proper medication reconciliation from pre- and post-surveys (16). Improving knowledge is important and may improve the quality of medication lists gathered through medication reconciliation, but the effect on outcomes is less clear (17-19). Similar to our findings, others have found that providing education alone is not enough to guarantee consistently accurate medication reconciliation (17-19). Additionally, a previous study conducted by our group identified numerous barriers to medication reconciliation including lack of time, lack of patient knowledge, and lack of a standardized 
workflow (4). While this work addressed the standardized workflow barrier, lack of time and lack of patient knowledge were again identified by participants in the current study as barriers to medication reconciliation (4).However, in implementation work a balance between adaptations to individual context of interventions and implementation strategies are important as long as key components are retained.

Our study is unique in that it mapped the implementation strategies to the Expert Recommendations for Implementing Change (ERIC) compilation (20), defined these strategies using a standardized guideline (10), and measured the implementation outcomes after deployment of an educational program. The measurement and analysis of these implementation outcomes generated important insights for the construction and implementation of future educational programs for medication reconciliation. Others have begun to map their implementation strategies for medication reconciliation to the ERIC compilation to create tailored strategies for the field (21). When implementing educational programs, all necessary staff should attend the full training to maximize benefit. Achieving this may require a change in policy or encouragement from clinic leadership. Educational programs should be flexible in their delivery methods of the content and recognize that certain methods work well for some clinics, but not for others. Most clinic personnel believe medication reconciliation is an important part of their job and were receptive of the training, but feasibility often hinders its application in practice, because of the barriers of insufficient time and patients not knowing their medications. Additionally, it is important to see if the findings from the educational program change practice and if these changes are sustainable over time. Our results indicate that while participants felt the training was applicable and appropriate many aspects of the medication reconciliation process were still not consistently adopted.

This study has a few limitations. While we did not observe all participants in the educational program, we conducted observations at three large sites and noted no significant differences between the sites. Adoption may be different at other sites or across individuals, but our data indicate more work is necessary to improve overall adoption of medication reconciliation best practices. Another limitation of our implementation strategy was that it targeted only one group of actors (healthcare personnel) and failed to address the other significant actor (patients). Participants in our study, consistent with previous studies (4), noted patient knowledge and behaviors limit the effectiveness of medication reconciliation. Future studies should examine sets of implementation strategies which target both healthcare personnel and patients, ideally addressing both the lack of time and lack of patient knowledge.

\section{Conclusion}

An educational program for medication reconciliation was found to be acceptable and appropriate but was often adapted to fit site specific needs. Additional barriers affected adoption of best practices and should be addressed in future studies.

\section{Declarations}

Ethics approval and consent to participate. This study was approved by the Geisinger's Institutional Review Board.

Consent for publication. Not applicable

Availability of data and materials. All data generated or analyzed during this study are included in this published article.

Competing interests. The authors declare that they have no competing interests.

Funding. This work was funded by the Geisinger Health Plan through the Geisinger Clinic Quality Pilot Fund program for fiscal years 2020 and 2021.

Authors' contributions. LKJ conceptualized and designed the study, acquired, analyzed, and interpreted the data, and drafted the initial and revised to final manuscript. VD helped to design the study, acquire, analyze, and interpreted the data, and helped to draft the initial and provided revisions to the final manuscript. KMR helped to design the study, interpret the data, and added substantial revisions to the initial and final manuscript. AF helped to acquire the data and added substantial revisions to the manuscript. JM helped to acquire the data and added substantial revisions to the manuscript. JG analyzed, and interpreted the data and added substantial contributions to the final manuscript. MRG helped to design the study, acquire, analyze and interpreted the data, and helped to draft the initial and provided revisions to the final manuscript.

All authors read and approved the final manuscript.

Acknowledgements. We would like to thank two Geisinger Commonwealth School of Medicine students, Evan Calvo and Gabriela Rodriguez, for completing the observations at the clinic sites.

\section{References}


1. Boockvar KS, Liu S, Goldstein N, Nebeker J, Siu A, Fried T. Prescribing discrepancies likely to cause adverse drug events after patient transfer. Qual Saf Health Care. 2009;18(1):32-6.

2. Kongkaew C, Noyce PR, Ashcroft DM. Hospital admissions associated with adverse drug reactions: a systematic review of prospective observational studies. The Annals of pharmacotherapy. 2008;42(7):1017-25.

3. Freeman WJ, Weiss AJ, Heslin KC. Overview of U.S. Hospital Stays in 2016: Variation by Geographic Region: Statistical Brief \#246. In: Healthcare Cost and Utilization Project (HCUP) Statistical Briefs. Rockville (MD): Agency for Healthcare Research and Quality (US); 2006.

4. Gionfriddo MRD, Middernacht V, Kern A, Graham MS, Wright J. E.A.;. A Mixed Methods Evaluation of Medication Reconciliation in the Primary Care Setting under review.

5. Proctor E, Silmere H, Raghavan R, Hovmand P, Aarons G, Bunger A, et al. Outcomes for implementation research: conceptual distinctions, measurement challenges, and research agenda. Adm Policy Ment Health. 2011;38(2):65-76.

6. Proctor EK, Landsverk J, Aarons G, Chambers D, Glisson C, Mittman B. Implementation research in mental health services: an emerging science with conceptual, methodological, and training challenges. Adm Policy Ment Health. 2009;36(1):24-34.

7. Drenth-van Maanen AC, Spee J, van Hensbergen L, Jansen PA, Egberts TC, van Marum RJ. Structured history taking of medication use reveals iatrogenic harm due to discrepancies in medication histories in hospital and pharmacy records. J Am Geriatr Soc. 2011;59(10):1976-7.

8. World Health Organization. High 5s: Standard operating procedures 2019 [Available from: https://www.who.int/patientsafety/topics/high5s/en/.

9. MARQUIS Investigators. MARQUIS Implementation Manual: A guide for medication reconciliation quality improvement. 2014.

10. Proctor EK, Powell BJ, McMillen JC. Implementation strategies: recommendations for specifying and reporting. Implement Sci. $2013 ; 8: 139$.

11. Harris PA, Taylor R, Thielke R, Payne J, Gonzalez N, Conde JG. Research electronic data capture (REDCap)-a metadata-driven methodology and workflow process for providing translational research informatics support. J Biomed Inform. 2009;42(2):377-81.

12. Harris PA, Taylor R, Minor BL, Elliott V, Fernandez M, O'Neal L, et al. The REDCap consortium: Building an international community of software platform partners. J Biomed Inform. 2019;95:103208.

13. Beebe J. Rapid assessment process: An introduction. Rowman Altamira; 2001.

14. Mekonnen AB, McLachlan AJ, Brien JA. Effectiveness of pharmacist-led medication reconciliation programmes on clinical outcomes at hospital transitions: a systematic review and meta-analysis. BMJ Open. 2016;6(2):e010003.

15. McNab D, Bowie P, Ross A, MacWalter G, Ryan M, Morrison J. Systematic review and meta-analysis of the effectiveness of pharmacist-led medication reconciliation in the community after hospital discharge. BMJ Qual Saf. 2018;27(4):308-20.

16. Lester PE, Sahansra S, Shen M, Becker M, Islam S. Medication Reconciliation: An Educational Module. MedEdPORTAL. $2019 ; 15: 10852$.

17. Mixon AS, Kripalani S, Stein J, Wetterneck TB, Kaboli P, Mueller S, et al. An On-Treatment Analysis of the MARQUIS Study: Interventions to Improve Inpatient Medication Reconciliation. J Hosp Med. 2019;14(10):614-7.

18. McDonald D, Mansukhani R, Kokotajlo S, Diaz F, Robinson C. Effect of Nursing Education on Optimization of Medication Reconciliation in the Pediatric Emergency Department. J Pediatr Pharmacol Ther. 2018;23(3):203-8.

19. Arundel C, Logan J, Ayana R, Gannuscio J, Kerns J, Swenson R. Safe Medication Reconciliation: An Intervention to Improve Residents' Medication Reconciliation Skills. J Grad Med Educ. 2015;7(3):407-11.

20. Powell BJ, Waltz TJ, Chinman MJ, Damschroder LJ, Smith JL, Matthieu MM, et al. A refined compilation of implementation strategies: results from the Expert Recommendations for Implementing Change (ERIC) project. Implement Sci. 2015;10:21.

21. Stolldorf DP, Ridner SH, Vogus TJ, Roumie CL, Schnipper JL, Dietrich MS, et al. Implementation strategies in the context of medication reconciliation: a qualitative study. Implement Sci Commun. 2021;2(1):63.

22. Additional File 1. Structured Observation Guide.

23. Annual Competency: Observation Checklist for Medication History.

24. Staff Member/Role.

25. Observer.

26. Date.

27. Clinic.

28. Verified patient's identity.

29. Verified. allergies.

30. Accessed patient's medical list.

31. Verified. preferred pharmacy.

32. Discussed. Mail Order Pharmacy as appropriate. 
33. Reviewed patient's medication list with the patient.

34. Used. go reconcile button.

35. Verify. Patient's current medication.

36. Are you using. your medication as prescribed? (Dose, Route, Frequency, etc.).

37. Asked. about new medication Added new medications.

38. Asked. about discontinued medications Removed old medications.

39. Asked about held medication. Mark as not taking.

40. Reason. discussed, if applicable.

41. Deleted. duplicates, if applicable.

42. Asked about side effects (adverse medication reactions).

43. Documentation. of reaction.

44. Asked about adherence (forgetfulness, trouble taking, or cost).

45. Ask about over the counter medications.

46. Asked. about "as needed" medications.

47. Asked about other concerns/questions.

48. Make note to Physician, if applicable.

49. Check. mark as review.

50. Areas. of Success.

51. Areas Needing Reinforcement/Action Taken.

52. Additional, File. 2. Semi-structured interview guide.

53. Interview Guide

54. Introduction. Thank you for agreeing to take part in this study. As a reminder, your participation in this study is voluntary. As you recall, we expect this part of the study to take up to 30 .

55. minutes. Your responses will help us learn more about the medication reconciliation training program being rolled out at Geisinger. Everything you tell me will be kept confidential. This means that your interview responses will only be shared with research team members not with your employer or anyone outside the research team. When we write our report on the interviews we are conducting, nothing in our report will identify you. Please be honest with your.

56. responses. You can say whatever you want - nothing will hurt my feelings and nothing you say will have a negative effect on your employment status. We will record this conversation, but the transcript from the conversation will not include any information that identifies.

57. you. Please remember: you don't have to talk about anything you don't want to talk about. You can decline to answer any question and you may end the interview at any time.

58. Is. it OK if I start recording now? (Utilize transcription service).

59. Interview Guide - Pharmacists.

60. General Understanding of Demographics.

61 . What is your role at Geisinger?

62. Responsibilities.

63. Prior to your. current role, do you have any prior experience in medication reconciliation?.

64. Years. in practice.

\section{General Understanding of the MedRec Training.}

66. In what format did you conduct the MedRec training?.

67. Virtual. or In-Person?.

68. Tell us about how the training went?.

69. Attitudes. toward the training?.

70. What. went well?.

71. What didn't go well?.

72. How was the training received by participants?

73. How was the attendance at the training?

74. What. discussions, if any, sparked during the training? 
75. How do you think the training could be improved?.

76. What. could hinder the rollout of this process?.

77. How sustainable. do you think this training will be over time?.

78. Why?.

79. If you were in. charge of fixing the process of medication reconciliation at Geisinger, what would you do to solve the problem?.

80. What other thoughts. would you like to share about the MedRec training you conducted?

81. Interview Guide - Clinical Staff.

82. General Understanding of Demographics.

83. What is your role at Geisinger?

84. Responsibilities.

85. Prior to your. current role, do you have any prior experience in medication reconciliation?.

86. Years. in practice.

87. General Understanding of the MedRec Training.

88. In what format did you receive the MedRec training?.

89. Virtual. or In-Person?

90. Tell us about how the training went?

91. Attitudes. toward the training?.

92. What. went well?.

93. What didn't go well?.

94. Do you feel the training was. well received by yourself and your co-workers?

95. What. discussions, if any, sparked during the training?.

96. How do you think the training could be improved?

97. How can we improve this training to meet your needs?.

98. What. could hinder the rollout of this process?.

99. How were you. able to incorporate what you learned from the training, in your day-to-day care with patients?.

100. Is it easy? Is it hard?.

101. How sustainable. do you think this training will be over time?.

102. Why?.

103. If you were in. charge of fixing the process of medication reconciliation at Geisinger, what would you do to solve the problem?

104. What other thoughts. would you like to share about the MedRec training you received?.

105. Closing. Thank you for participating today. We are trying to get a comprehensive understanding of the medication reconciliation training being rolled out at Geisinger. Is there anyone else that we should contact to who might be able to provide their additional insight into this training?.

106. For participating. you will receive a \$25 e-gift card to Amazon. I will be sending this through to your email.

\section{Supplementary Files}

This is a list of supplementary files associated with this preprint. Click to download.

- TIDieRChecklistPDF.pdf 